\title{
High Temperature Induced Glume Closure Resulted in Lower Fertility in Hybrid Rice Seed Production
}

\author{
Haoliang Yan ${ }^{1,2}$, Binglin Zhang ${ }^{1,2}$, Yunbo Zhang, ${ }^{1,2}$, Xinlan Chen ${ }^{1}$, Hui Xiong ${ }^{1}$, \\ Tsutomu Matsui ${ }^{2,3}$ and Xiaohai Tian ${ }^{1,2 *}$ \\ ${ }^{1}$ Agricultural College, Yangtze University, Jingzhou, China, ${ }^{2}$ Hubei Collaborative Innovation Center for Grain Industry, \\ Jingzhou, China, ${ }^{3}$ Applied Biological Faculty, Gifu University, Gifu, Japan
}

OPEN ACCESS

Edited by: Bingru Huang,

Rutgers University, USA

Reviewed by:

Meixue Zhou,

University of Tasmania, Australia

Manuel Enrique Pinto,

Instituto Nacional de Investigación y

Tecnología Agraria y Alimentaria, Chile

*Correspondence:

Xiaohai Tian

xiaohait@sina.com

Specialty section:

This article was submitted to Crop Science and Horticulture, a section of the journal

Frontiers in Plant Science

Received: 06 September 2016

Accepted: 12 December 2016

Published: 05 January 2017

Citation:

Yan $H$, Zhang B, Zhang Y, Chen X, Xiong H, Matsui T and Tian X (2017)

High Temperature Induced Glume Closure Resulted in Lower Fertility in Hybrid Rice Seed Production.

Front. Plant Sci. 7:1960.

doi: 10.3389/fpls.2016.01960
Predicted climate changes, in particular, the increased dimension and frequency of heat waves, are expected to affect crop growth in the future seriously. Hybrid rice relies on seed production from male sterile and restorer lines. Experiments were conducted over two consecutive years to compare the high temperature tolerance of parents of different hybrid rice combinations, in terms of fertility rate, flowering pattern, pollination and physiological parameters of the lodicule. Three male sterile lines and a broad compatibility restorer line (as pollen donor and conventional variety as well) were grown to heading stage and then treated with average daily temperatures of $26^{\circ} \mathrm{C}$ (range 23$\left.30^{\circ} \mathrm{C}\right), 28^{\circ} \mathrm{C}\left(25-32^{\circ} \mathrm{C}\right)$, and $30^{\circ} \mathrm{C}\left(26-34^{\circ} \mathrm{C}\right)$, respectively, continued for $5-7$ days each in a natural light phytotron which simulated the local typical high temperature weather in the field. The results indicated that male sterile lines were more sensitive to high temperature than the restorer line for fertility rate, and the sensitivity varied between varieties. The fertility rate of the restorer line was maintained at about $90 \%$ under the high temperature treatments, while it decreased in the male sterile lines by 23.3 and $48.1 \%$ at 28 and $30^{\circ} \mathrm{C}$, respectively. The fertility rate of the most sensitive line declined by $70 \%$, and the tolerant line declined by $34 \%$ at $30^{\circ} \mathrm{C}$. Glume closure in the male sterile lines was a major reason for the reduced fertility rate under high temperature, which is closely correlated with carbohydrates content and the vascular bundle pattern in the lodicule. The present study identified a useful trait to select male sterile lines with high temperature tolerance for seed production.

Keywords: high temperature, male sterile line, seed production, glume closure, lodicule, rice

\section{INTRODUCTION}

Rice is the staple food for more than half of the world's population. Rice production in East Asia, Southeast Asia and African countries is important for global food security (Seck et al., 2012). Rice yields in China have been increased rapidly due to the wide application of hybrid rice, which occupies nearly $50 \%$ of the total rice planting areas (Cheng et al., 2007; Singh et al., 2015).

Based on the Intergovernmental Panel on Climate Change (IPCC ) Fifth Assessment Report (Stocker et al., 2013), the globally averaged temperature in 2012 was $0.85^{\circ} \mathrm{C}$ higher than in 1880 . It is expected that this temperature increment may increase to more than $1.5^{\circ} \mathrm{C}$ by the end of the $21 \mathrm{st}$ century, and the air temperature in China is likely to be $0.3-0.7^{\circ} \mathrm{C}$ higher in the next two decades 
than that in 1986-2005 (Shen and Wang, 2013). In the last 117 years, the Yangtze River Basin has had the highest average air temperatures (Tu et al., 1999) and more frequent heat waves than ever before.

Seed production is a critical step in hybrid rice production, in which a male sterile line and a restorer line are used to produce hybrid seeds. Annual hybrid seed production area in China is around 100,000-130,000 ha, average seed yield is 2.4 $\mathrm{t} / \mathrm{ha}$ and the Yangtze River Basin is the major seed production area (Li et al., 2009; Li and Yuan, 2010; Wang et al., 2011). In recent years, heat or high temperature has become an apparent issue to rice production in Yangtze River Basin, the biggest rice band in China. In 2003, the heat wave happened in late July and up part of August across this area, leading to a big rice yield loss worth up to US\$30,700,000 (Tian et al., 2008). Ten years later, a big heat happened again, leading to 60$80 \%$ yield reduction in the hybrid rice seed production (Yan et al., 2014, 2015). For hybrid seed production, the parents are sowing in a specific period so that they flower at a period when the extreme temperatures (cold or heat) unlikely happen. However, unpredictable heat shock can still happen, for example, the 2013 growing season. Thus, high temperature has become an important limitation to hybrid rice seed production in China.

The stamen is particularly vulnerable to high temperature (Hasanuzzaman et al., 2013; Mesihovic et al., 2016). For conventional rice varieties, temperatures above $33.7^{\circ} \mathrm{C}$ can negatively impact the anther dehiscence, which in turn can reduce the number of pollen reaching the stigma and eventually the fertility rate and yield (Satake and Yoshida, 1978; Matsui et al., 2000; Jagadish et al., 2011). However, little is known on how the hybrid rice seed production system responds to high temperature. A number of studies have identified QTLs for heat tolerance at the flowering stage of rice, but genetically how parent plants of hybrid rice adapt to heat stress is lacking (Cao et al., 2003; Xiao et al., 2011; Ye et al., 2012, 2015).

We tested the hypothesis that hybrid rice seed production is more susceptible to high temperature than conventional rice varieties, and genotypic differences for high-temperature tolerance exist among male sterile lines. We treated three male sterile lines and one rice restorer with three different temperatures, and measured fertility rates, flowering patterns, and the physiological parameters of the lodicule to reveal the mechanisms of hybrid rice responding to high temperature.

\section{MATERIALS AND METHODS}

\section{Plant Materials}

Three male sterile lines-Guangzhan 63S, Y58S, II-32A-and one broad compatibility restorer line 9311 (as a normal pollen donor and a conventional rice variety as well) were selected for this study. The three male sterile lines have been widely used for commercial hybrid seed production; Guangzhan 63S and Y58S have been used in two-line hybrid seed production and II-32A has been used in three-line hybrid seed production.

\section{Plant Growth and Treatment}

A pot experiment was carried out at the experimental farm of Yangtze University $\left(112^{\circ} 31^{\prime} \mathrm{E}, 30^{\circ} 21^{\prime} \mathrm{N}\right)$ in 2014 and 2015 . The four varieties were planted in four batches of six pots each, and an extra eight batches of the restorer line 9311 were planted in the field ( $12 \mathrm{~m}^{2}$ plot area) to produce enough normal pollen to pollinate the male sterile lines. Planting dates for each line are in Supplementary Tables S1 and S2.

Twenty-day-old seedlings were transplanted into each plastic pot (inner diameter $30 \mathrm{~cm}$, height $30 \mathrm{~cm}$ ) containing $12.5 \mathrm{~kg}$ soil and $8 \mathrm{~g}$ N: P: K compound fertilizer (26:10:15). The tillers were cut off leaving only the main stem during the plant culture. The plants were grown to heading stage and then transferred before anthesis to a growth chamber (AGC-MR, Zhejiang Qiushi Environment Co., Ltd, Zhejiang, China) for temperature treatment. The air temperature was dynamically controlled in accordance with the diurnal variation of air temperature simulating local typical heat weather conditions (Supplementary Table S3). Exactly, as the temperature treatment, the average daily temperatures were set to be 26,28 and $30^{\circ} \mathrm{C}$, respectively, with a constant relative humidity of $75 \%$. In each treatment, plants were treated for 5-7 days during flowering and the restorer plants (planted in the field as pollen donor) were transferred to the phytotron next to the male sterile lines for pollination. Hand pollination was carried out to ensure that the spikelet was fully pollinated when the male sterile lines were flowering. The pollen donor restorer plants were transferred from the field to the phytotron every day to ensure an enough pollen supply.

\section{Flowering Patterns}

To clarify the flowering patterns of each line under the various temperature regimes, we counted the spikelets which opened on the panicle each day during anthesis. The number of flowering spikelets in per panicle was counted every 15 to $30 \mathrm{~min}$ from 8:00 to 17:00 until all the spikelets were opened on the panicle; newly opened spikelets were counted and marked. At this time, the total number of opened spikelets (spikelets had opened during flowing time) and the number of closure glumes (spikelets without markers, means those spikelets were never opened) were determined for each panicle. The total number of stigma exserted spikelets of each selected panicle was also counted, recognized by stigma traces at the side(s) of the glume. Comparing the flowering periods of the spikelets in male sterile lines with the restorer line 9311, synchronization flowering was defined as the overlap. Otherwise, they were considered as non-synchronization flowering.

The following formulas were used to calculate various parameters:

Percentage of glume closure per panicle $=$ (the number of closure glumes spikelets/the total number of spikelets $) \times 100 \%$

Percentage of synchronization flowering per panicle $=$ (the number of spikelets synchronized opening/the total number of flowered spikelets) $\times 100 \%$ 
Stigma exsertion rate per panicle $=$ (the number of stigmas exserted/the total number of spikelets) $\times 100 \%$

\section{Pollinated and Germinated Pollen Numbers on the Stigma}

Pollinated pollen numbers were determined as described by Matsui and Kagata (2003). Twenty florets from each line in each treatment were successively collected between 14:00 and 15:00 for 5 days. All samples were stored in an ice box until the stigma was isolated and stained for 10 days with cotton blue. The total numbers of pollen and germinated pollen grains were then counted under a microscope, and the pollen germination rate was calculated.

\section{Vascular Distribution in Lodicule}

Measurements of vascular distribution in lodicule were modified from Wang et al. (1991). In 2014, 20 spikelets were collected from each line in each treatment between 7:00 and 8:00 and fixed in FAA fixative. The lodicule was then detached, rinsed and treated with lactic acid for $12 \mathrm{~h}$ until it became transparent. The distribution and number of vascular bundles were recorded using an optical microscope. In 2015, 50 spikelets of each line were random collected from three treatments, measurements were same as in 2014.

\section{Contents of Soluble Sugar and Starch in Lodicule}

Measurements of soluble sugar and starch were modified from Wang et al. (1991). Fifty spikelets of each line from each treatment were sampled between 7:00 and 8:00 during flowering in 2015; the lodicules were isolated and snap frozen in liquid nitrogen. Each sample consisted of 100 pairs of lodicules with three replications. Soluble sugars in the lodicule were extracted with $80 \%(\mathrm{v} / \mathrm{v})$ ethanol by incubating for $30 \mathrm{~min}$ at $80^{\circ} \mathrm{C}$ and subsequently quantified using the anthrone colorimetric method. The lodicule residue was dried at $60^{\circ} \mathrm{C}$ and then digested in 4.6 $\mathrm{N}$ perchloric acid for starch extraction. The starch in the supernatant was determined using the anthrone colorimetric method.

\section{Determination of Fertility Rate}

Thirty panicles of each line in each treatment were grown to maturity and then harvested to determine the fertility rate (Prasad et al., 2006; Zhao et al., 2010). The fertilized spikelet was determined by its kernel plumpness, both completely and partially filled kernels were considered as fertilized kernels. The fertility rate of each panicle was calculated using the following formula:

Fertility rate $=$ (number of fertilized kernels/total spikelet number) $\times 100 \%$.

\section{Statistical Analysis}

Statistical analyses were carried out with SAS 9.2. All the data were analyzed by ANOVA to evaluate the main effects of variety and treatment. Duncan tests $(P<0.05)$ were used to detect significant differences between means. Relationships between each index were analyzed by linear regressions.

\section{RESULTS}

\section{Fertility Rate}

Fertility rates in the two-year experiments were shown in Table 1. The restorer 9311 was not significantly impacted by high temperatures in term of fertility rate, with an average rate around $90 \%$ in 2 years. Fertility rates of the three male sterile lines showed a decreasing pattern along with the increasing temperature (except for the data point of II-32A in 2015), although increasing temperature had larger impact on fertility rate in 2014. Male sterile lines showed dramatically different response to increasing temperature. II-32A has the best tolerance to the higher temperature. Its fertility rate maintain stable or slightly increase when the average temperature increased from 26 to $28^{\circ} \mathrm{C}$ in 2015 . When the temperature was increased to from 26 to $30^{\circ} \mathrm{C}$, the fertility rate was decreased by $34.1 \%$ in 2 years' average. Y58S exhibited moderate tolerance to the increasing temperature. When the temperature was increased to from 26 to $30^{\circ} \mathrm{C}$, the fertility rate was decreased by $48.4 \%$. On the other hand, Guangzhan 63S exhibited higher sensitivity to increasing temperature. Its fertility rate was decreased by $75.6 \%$ when the average temperature increased from 26 to $28^{\circ} \mathrm{C}$.

\section{Flowering Patterns}

Flowering time differed between varieties at different temperatures (Figure 1). At high temperatures, the restorer 9311 flowered earlier and for a shorter duration than at $26^{\circ} \mathrm{C}$, but had little effect on the male sterile line II-32A (except $30^{\circ} \mathrm{C}$ in 2014). Besides, the fluorescent spikelets of II-32A could be observed from 9:00 to 16:00, indicating a relatively long but scattered flowering pattern. Y58S had different flowering patterns to II-32A, with a longer flowering period at a lower temperature and fewer fluorescent spikelets at higher temperatures. Guangzhan63S showed similar tendencies with Y58S. Besides, Guangzhan63S had lower fluorescent spikelets than other two male sterile lines, especially under $26^{\circ} \mathrm{C}$ in 2014.

At high temperatures, the shorter flowering duration in the restorer 9311 resulted in fewer florets flowering synchronization with the three male sterile lines (Table 2). For instance, at $26^{\circ} \mathrm{C}$ in 2015 , an average of $86.6 \%$ spikelets synchronized their flowering time with the male sterile lines but this rate declined to 83.0 and $71.9 \%$ at 28 and $30{ }^{\circ} \mathrm{C}$, respectively. II-32A and Guangzhan 63S had significantly lower rates of synchronizing flowering time at higher temperatures. However, compared to that at $26^{\circ} \mathrm{C}$, Y $58 \mathrm{~S}$ had a small increase in the rate of synchronizing flowering time at $28^{\circ} \mathrm{C}$, due to the earlier blooming time of the restorer line 9311.

II-32A had the highest percentage of glume closure at $26^{\circ} \mathrm{C}$ in 2015 , which was significantly higher than at higher temperatures. In contrast, Y58S and Guangzhan 63S had a higher rate of glume closure with increasing temperature. Y58S had a remarkable 
TABLE 1 | The fertility rate of each variety with varied temperature (in daily mean temperature) treatment in 2014 and 2015.

\begin{tabular}{|c|c|c|c|c|}
\hline Treatment & \multicolumn{4}{|c|}{ Fertility rate (\%) } \\
\hline \multicolumn{5}{|l|}{$2014^{a}$} \\
\hline $26^{\circ} \mathrm{C}$ & $92.18 \pm 2.22 \mathrm{a}$ & $30.33 \pm 6.84 a$ & $45.86 \pm 12.79 a$ & $12.53 \pm 8.21 a$ \\
\hline $28^{\circ} \mathrm{C}$ & $88.41 \pm 6.58 \mathrm{a}$ & $23.47 \pm 9.92 b$ & $23.24 \pm 9.50 b$ & $4.32 \pm 4.88 b$ \\
\hline $30^{\circ} \mathrm{C}$ & $89.56 \pm 3.06 a$ & $12.61 \pm 7.41 \mathrm{c}$ & $16.33 \pm 9.59 c$ & $5.73 \pm 4.11 b$ \\
\hline $28^{\circ} \mathrm{C}$ & $92.26 \pm 1.42 \mathrm{a}$ & $35.76 \pm 5.35 a$ & $26.56 \pm 9.95 b$ & $6.62 \pm 3.55 b$ \\
\hline $30^{\circ} \mathrm{C}$ & $87.73 \pm 4.10 b$ & $37.02 \pm 11.99 a$ & $22.62 \pm 9.58 c$ & $7.92 \pm 4.48 b$ \\
\hline \multicolumn{5}{|c|}{ Annual mean } \\
\hline $26^{\circ} \mathrm{C}$ & $88.06 \pm 5.64 b$ & $35.12 \pm 4.54 a$ & $37.76 \pm 13.90 a$ & $22.38 \pm 15.88 a$ \\
\hline $28^{\circ} \mathrm{C}$ & $90.33 \pm 5.10 a$ & $35.90 \pm 14.07 a$ & $35.90 \pm 16.01 a$ & $5.47 \pm 4.38 b$ \\
\hline
\end{tabular}

${ }^{a}$ Data are means \pm SE. $n=25,{ }^{b} n=50,25$ of 2014 and 25 of 2015. Different letters within a column indicate significant differences at $P<0.05$ in the same variety.
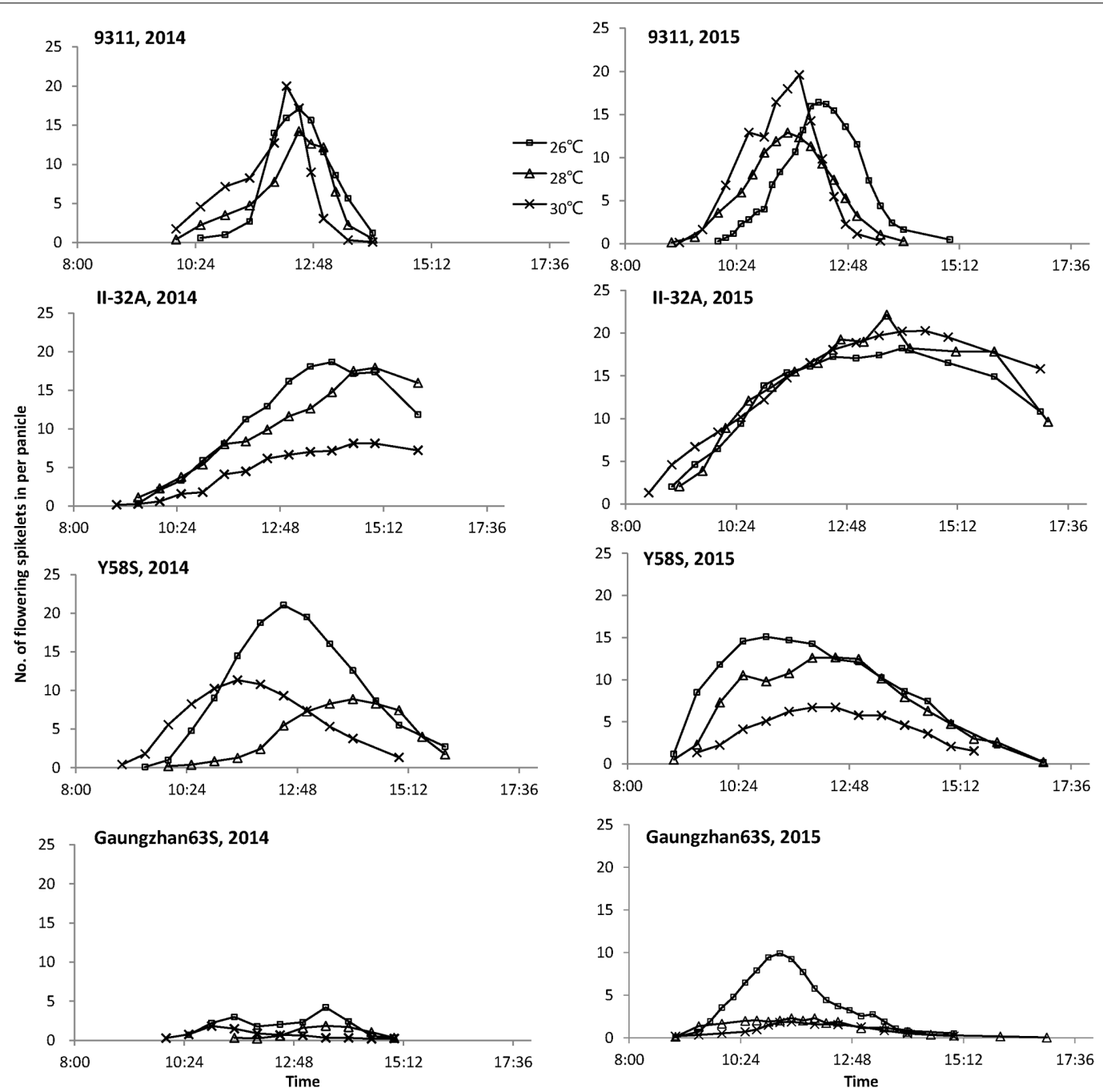

FIGURE 1 | Daily time course of flowering spikelets of each variety under various temperature treatments. These figures are based on the data collected from eight panicles of each variety during anthesis in 2014 and 2015. 
TABLE 2 | Percentage of synchronization flowering per panicle(against the restorer line 9311), percentage of glume closure per panicle, and stigma exsertation rate per panicle in various male sterile line varieties under varied temperature treatment.

\begin{tabular}{|c|c|c|c|c|}
\hline Variety & Treatment & $\begin{array}{l}\text { Percentage of synchronization } \\
\text { flowering per panicle }(\%)^{a}\end{array}$ & $\begin{array}{c}\text { Percentage of glume } \\
\text { closure per panicle (\%) }\end{array}$ & $\begin{array}{c}\text { Stigma exsertation rate per } \\
\text { panicle }(\%)^{\mathrm{a}}\end{array}$ \\
\hline \multirow[t]{3}{*}{$\|-32 A$} & $26^{\circ} \mathrm{C}$ & $87.17 \pm 0.53 a^{b}$ & $33.12 \pm 2.68 a$ & $47.14 \pm 2.22 b$ \\
\hline & $28^{\circ} \mathrm{C}$ & $73.58 \pm 2.96 b$ & $9.61 \pm 1.66 \mathrm{~b}$ & $69.98 \pm 2.14 a$ \\
\hline & $30^{\circ} \mathrm{C}$ & $68.45 \pm 1.54 b$ & $14.14 \pm 2.80 \mathrm{~b}$ & $65.53 \pm 2.82 a$ \\
\hline \multirow[t]{3}{*}{ Y58S } & $26^{\circ} \mathrm{C}$ & $76.89 \pm 2.45 b$ & $7.53 \pm 1.69 b$ & $79.30 \pm 0.76 a$ \\
\hline & $28^{\circ} \mathrm{C}$ & $85.55 \pm 1.27 a$ & $10.11 \pm 0.95 b$ & $79.86 \pm 0.84 a$ \\
\hline & $30^{\circ} \mathrm{C}$ & $65.76 \pm 2.03 c$ & $19.37 \pm 2.61 a$ & $59.18 \pm 5.32 b$ \\
\hline \multirow[t]{3}{*}{ Guangzhan63S } & $26^{\circ} \mathrm{C}$ & $95.85 \pm 1.65 a$ & $15.02 \pm 3.21 b$ & $44.74 \pm 5.02 a$ \\
\hline & $28^{\circ} \mathrm{C}$ & $89.64 \pm 1.03 \mathrm{ab}$ & $51.26 \pm 3.22 a$ & $12.05 \pm 2.38 b$ \\
\hline & $30^{\circ} \mathrm{C}$ & $81.38 \pm 3.81 b$ & $49.81 \pm 3.08 a$ & $11.79 \pm 2.77 b$ \\
\hline
\end{tabular}

aEight panicles of each variety were selected randomly during anthesis for data collection in 2015.

${ }^{\mathrm{b}}$ Data are means \pm SE. Different letters within a column indicate significant differences at $P<0.05$ in the same variety.

increase in the percentage of glume closure at $30^{\circ} \mathrm{C}$, while Guangzhan $63 \mathrm{~S}$ had a similar pattern even at $28^{\circ} \mathrm{C}$.

\section{Stigma Exsertion Rate}

The stigma exsertion rate showed almost a same tendency as the glume closure rate under various temperatures (Table 2). The stigma exsertion rate increased with increasing temperature for II-32A but decreased for Y58S and Guangzhan 63S. Guangzhan $63 \mathrm{~S}$ was more sensitive to high temperature stress than the other lines, having a low stigma exsertion rate at $28^{\circ} \mathrm{C}$. In contrast, the stigma exsertion rate for $\mathrm{Y} 58 \mathrm{~S}$ did not significantly differ at $26^{\circ} \mathrm{C}$ or $28^{\circ} \mathrm{C}$, but dramatically declined at $30^{\circ} \mathrm{C}$.

\section{Pollination Properties}

In 2015, the average number of pollen per stigma on the three male sterile lines was 3.7 , which was only $6.7 \%$ of the restorer line 9311 (9.99 and 4.76\% in 2014), indicating that the fertility rate of male sterile lines may be hampered by limited pollen numbers for outcrossing. The number of pollen grains on each stigma increased in the restorer line 9311 at higher temperatures, but the male sterile lines decreased (except for II-32A at $26^{\circ} \mathrm{C}$ in 2015 ; Figure 2).

The percentage of germinated pollen in the restorer line 9311 did not differ in response to temperature in either year, suggesting that both the male and female reproductive organs in the restorer line were not affected by the temperature treatments (Figure 3). For the male sterile lines, pollen germination rates for Y58S and Guangzhan $63 \mathrm{~S}$ did not change with increasing temperatures, while that of II-32A decreased.

\section{Physiological Characters of Lodicule}

The number of vascular bundles varied significantly among varieties (Figure 4), but not among treatments (Table 3). II-32A had the fewest vascular bundles. Y58S and the restore line 9331 had a moderate abundance of vascular bundles, which were four times more than II-32A. Guangzhan $63 \mathrm{~S}$ had the most vascular bundles.

Lodicule starch contents before glume opening did not differ between varieties or among treatments, except for Guangzhan $63 \mathrm{~S}$, which significantly decreased at higher temperatures.

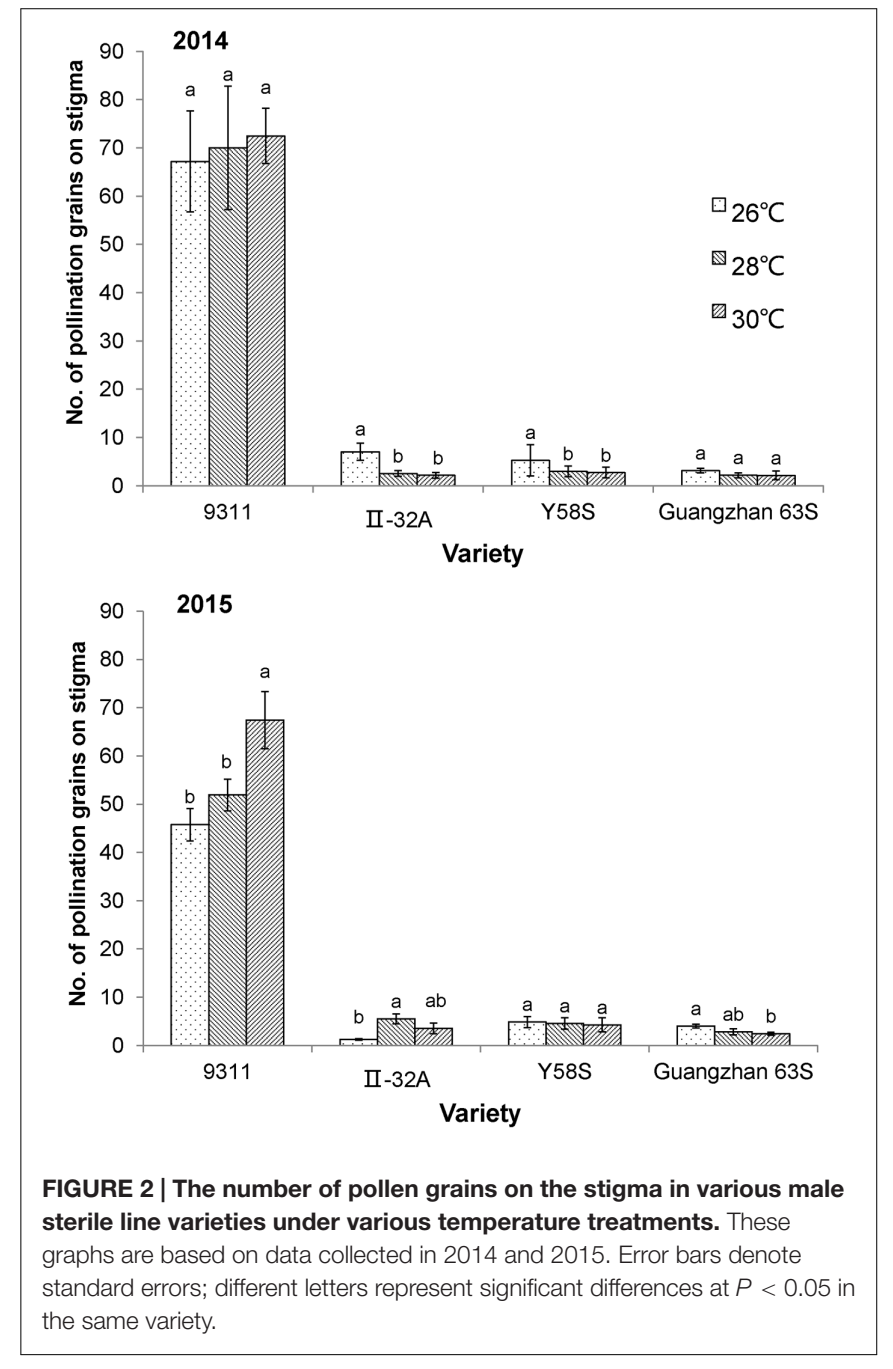

No significant changes in soluble sugar or starch content in the lodicule were observed in II-32A or Y58S at different temperatures (Table 4). The soluble sugar content in the lodicule of 9311 increased with temperature, as did starch content. 


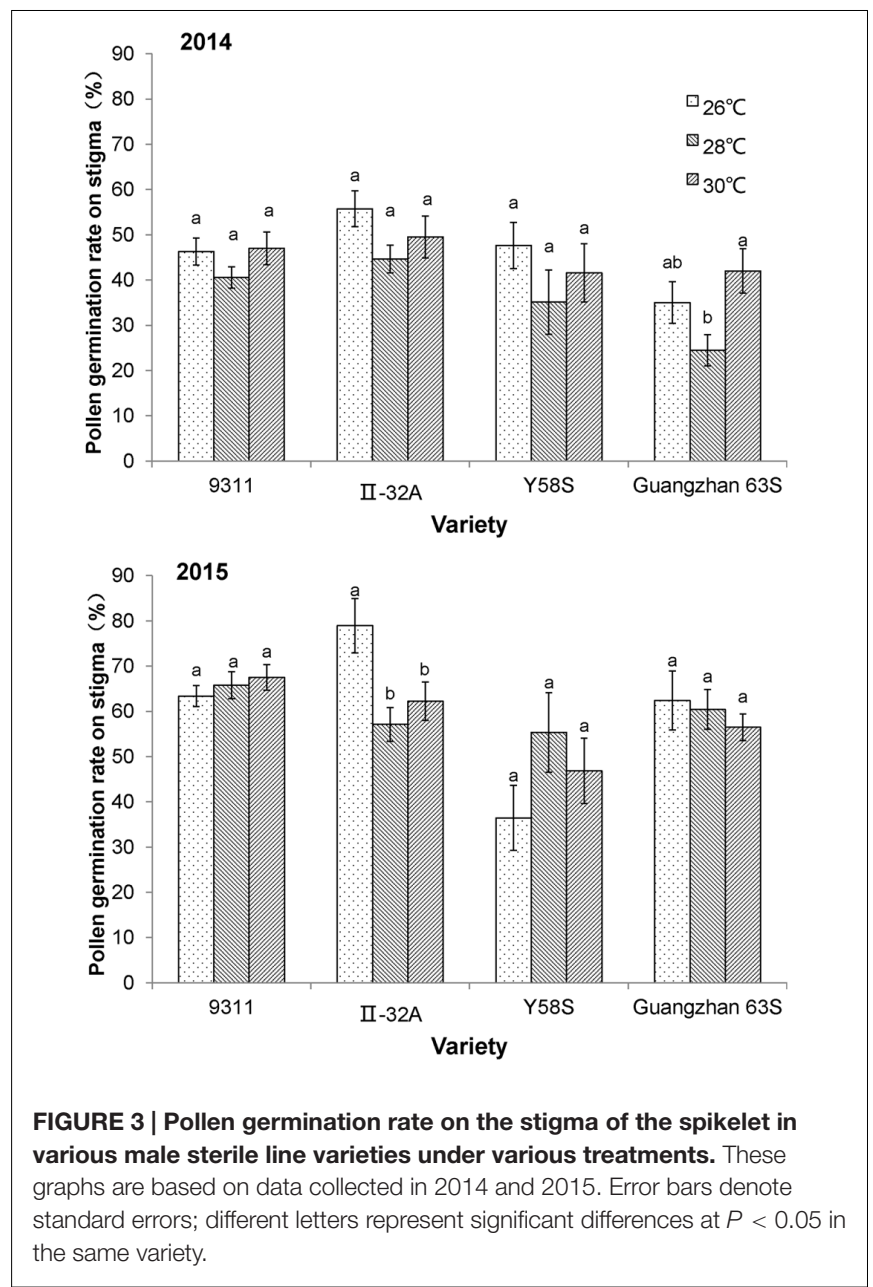

\section{DISCUSSION}

High temperature can adversely affect crop growth and development, with the reproductive stage generally more sensitive to high temperature than the vegetative stage. The stamen is especially vulnerable to high temperature (Hasanuzzaman et al., 2013; Mesihovic et al., 2016). For conventional rice varieties, temperatures above $33.7^{\circ} \mathrm{C}$ can impact anther dehiscence and disperse pollen grains, which reduce pollen numbers on the stigma and, eventually, the fertility rate and yield (Satake and Yoshida, 1978; Matsui et al., 2000; Jagadish et al., 2011). Seed production is a critical step in hybrid rice production, where a male sterile line and a restorer line are used to produce hybrid seeds. Success is entirely dependent on cross-pollination. Little information is available on how the hybrid seed production system responds to high temperatures. Our study showed significant reductions in the fertility rate of some male sterile lines when the average daily temperature reached above $28^{\circ} \mathrm{C}$ or the highest daily temperature reached $32^{\circ} \mathrm{C}$ compared with $33.7^{\circ} \mathrm{C}$ observed for conventional rice varieties (Matsui et al., 2000; Jagadish et al., 2011). Our results are consistent with previous reports that the high temperature stress threshold for hybrid rice seed production is around $28^{\circ} \mathrm{C}$

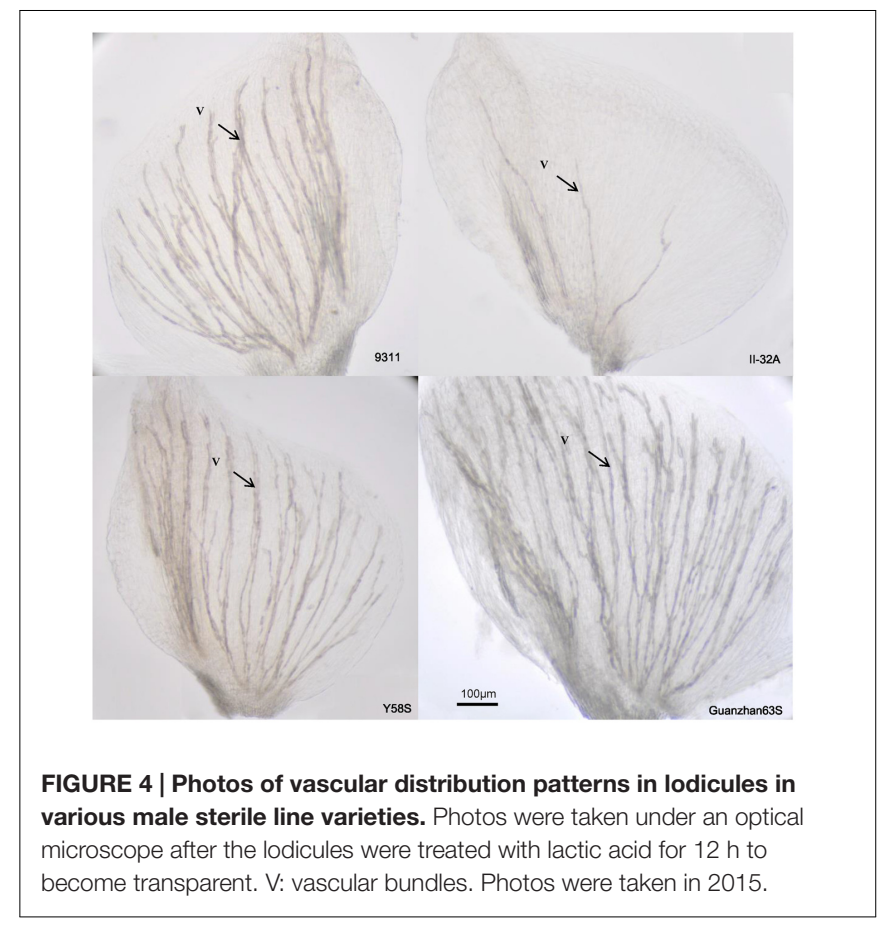

at the heading stage in the field (Yan et al., 2014, 2015). Our study also confirmed that hybrid rice seed production is more sensitive to high temperature and that the warning temperature for high temperature damage is about $2^{\circ} \mathrm{C}$ lower in hybrid rice seed production than in conventional varieties.

Cleistogamy is believed to be a protective mechanism against high-temperature damage during anthesis. This phenomenon has been observed in some commercial rice varieties ( $\mathrm{Li}, 1988$; Das et al., 2014). Koike et al. (2015) generated a temperatureinducible cleistogamous rice mutant and found that cleistogamy was advantageous to rice pollination and fertilization at high temperatures. However, the hybrid rice seed production system is entirely dependent on cross-pollination between a male sterile line and a restorer line. The cleistogamy mechanism would not be suitable for the male sterile line against high-temperature damage. Instead, glume closure in male sterile lines under high temperature leads to less available pollen for pollination. Our results demonstrated that the fertility rate was significantly associated with the percentage of glume-closed florets $(r=$ $-0.85^{* *}$, Supplementary Figure S1) and the percentage of exserted stigmas $\left(r=0.97^{* *}\right.$, data not shown). Also, the percentage of exserted stigmas was negatively correlated with the percentage of glume-closed florets $\left(r=-0.93^{* *}\right.$, Supplementary Figure S1). Hence, glume closure may be the main reason for reduced fertility rates in hybrid rice seed production at high temperature. For conventional rice, high temperature during anthesis adversely affected anther dehiscence and spreading, which reduced pollination and fertilization as well as fertility rate (Togari and Kashiwakura, 1958; Yoshida et al., 2007). In contrast, the pollination of male sterile lines relies on pollen donation from the male parent (the restorer line). In the present study, the fertility of pollen from restorer line 9311 under various 
TABLE 3 | The number of vascular bundles in per lodicule.

\begin{tabular}{|c|c|c|c|c|}
\hline \multirow[t]{2}{*}{ Treatment } & \multicolumn{4}{|c|}{ No. of vascular bundles in per lodicule } \\
\hline & 9311 & II-32A & Y58S & Guangzhan 635 \\
\hline \multicolumn{5}{|l|}{$2014^{a}$} \\
\hline $26^{\circ} \mathrm{C}$ & $17.00 \pm 0.41 a$ & $2.95 \pm 0.22 a$ & $17.25 \pm 0.56 a$ & $21.80 \pm 0.56 a$ \\
\hline $28^{\circ} \mathrm{C}$ & $16.95 \pm 0.47 a$ & $3.10 \pm 0.20 a$ & $18.60 \pm 0.53 a$ & $22.95 \pm 0.46 a$ \\
\hline $30^{\circ} \mathrm{C}$ & $17.30 \pm 0.60 a$ & $3.00 \pm 0.27 a$ & $17.10 \pm 0.53 a$ & $21.70 \pm 0.45 a$ \\
\hline \multicolumn{5}{|l|}{$2015^{b}$} \\
\hline & $17.66 \pm 0.43$ & $4.20 \pm 0.18$ & $17.34 \pm 0.37$ & $21.68 \pm 0.35$ \\
\hline
\end{tabular}

${ }^{a}$ Data are means $\pm S E, n=20 .{ }^{\mathrm{b}} n=50$. Different letters within a column indicate significant differences at $P<0.05$ in the same variety.

TABLE 4 | Starch and soluble sugar content in each pair of lodicules in various male sterile line varieties under various treatments.

\begin{tabular}{|c|c|c|c|}
\hline Variety & Treatment & $\begin{array}{l}\text { Starch content in each pair of } \\
\text { lodicules }(\mu \mathrm{g})^{\mathrm{a}}\end{array}$ & $\begin{array}{c}\text { Soluble sugar content in each } \\
\text { pair of lodicules }(\mu \mathrm{g})^{\mathrm{a}}\end{array}$ \\
\hline \multirow[t]{3}{*}{9311} & $26^{\circ} \mathrm{C}$ & $3.96 \pm 0.38 a^{b}$ & $6.28 \pm 0.64 b$ \\
\hline & $28^{\circ} \mathrm{C}$ & $3.92 \pm 0.92 a$ & $7.32 \pm 0.81 a b$ \\
\hline & $30^{\circ} \mathrm{C}$ & $4.68 \pm 0.67 a$ & $8.69 \pm 0.64 a$ \\
\hline \multirow[t]{3}{*}{ II-32A } & $26^{\circ} \mathrm{C}$ & $2.79 \pm 0.32 a$ & $7.29 \pm 0.74 b$ \\
\hline & $28^{\circ} \mathrm{C}$ & $2.33 \pm 0.83 a$ & $10.87 \pm 0.34 a$ \\
\hline & $30^{\circ} \mathrm{C}$ & $2.59 \pm 0.11 a$ & $7.94 \pm 0.58 b$ \\
\hline \multirow[t]{3}{*}{ Y58S } & $26^{\circ} \mathrm{C}$ & $2.91 \pm 0.36 a$ & $10.96 \pm 0.27 b$ \\
\hline & $28^{\circ} \mathrm{C}$ & $2.65 \pm 0.78 a$ & $13.34 \pm 2.19 a$ \\
\hline & $30^{\circ} \mathrm{C}$ & $2.98 \pm 0.68 a$ & $10.79 \pm 0.95 b$ \\
\hline \multirow[t]{3}{*}{ Guangzhan 63S } & $26^{\circ} \mathrm{C}$ & $3.89 \pm 3.89 a$ & $12.93 \pm 0.45 a$ \\
\hline & $28^{\circ} \mathrm{C}$ & $3.33 \pm 3.33 \mathrm{ab}$ & $4.76 \pm 0.74 c$ \\
\hline & $30^{\circ} \mathrm{C}$ & $2.98 \pm 2.98 b$ & $7.18 \pm 1.06 b$ \\
\hline
\end{tabular}

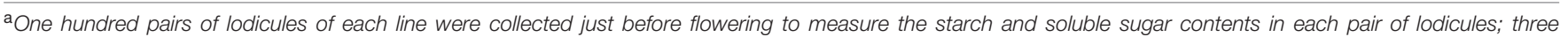
replications were measured in 2015.

${ }^{\mathrm{b}}$ Data are means \pm SE. Different letters within a column indicate significant differences at $P<0.05$ in the same variety.

temperature treatments were similar (data not shown), but the average number of pollen per stigma in male sterile lines were 3.7, far less than the lower limits in conventional rice (Togari and Kashiwakura, 1958; Yoshida et al., 2007). Thus, the decreasing fertility rate in male sterile lines was probably due to the fewer stigmas exposed to available pollen from restorer lines, resulting from glume closure at high temperature. Glume closure in response to high temperature should be considered an important trait for heat tolerance. For conventional rice varieties, sensitivity to increasing temperature for glume closure may be a favorable trait for high-temperature tolerance as cleistogamy will reduce the high temperature damage. On the other hand, a lack of sensitivity to increasing temperature for glume closure may be a favorable trait for the male sterile line as this should increase the cross-pollination rate at higher temperatures.

Glume opening/closing in rice is mainly caused by changes in water potential which is regulated by osmotic pressure in lodicules (Wang et al., 1991). The abundance of vascular bundles is favored for the rapid absorption and release of water in lodicules during the opening and closing of the lemma and palea (Wang et al., 1992). In the present study, high temperature reduced soluble sugar and starch contents in lodicules before flowering, both of which were negatively correlated $(P<0.001$, data not shown) with the glume closure rate, particularly in
Guangzhan 63S, which had the largest variation in glume closure rate at high temperature. We also observed that Guangzhan 63S had abundant vascular tissues in lodicules, which is in contrast to II-32A, which had a low abundance of vascular tissues and a broader flowering time. Thus, abundant vascular tissues in lodicules may be a favorable trait for high-temperature tolerance in conventional rice varieties as it could close the glume quickly in response to higher temperature to protect the stamen (Li, 1988; Koike et al., 2015). However, this trait becomes unfavorable for hybrid seed production as glume closure prevents outcrossing pollination. Male sterile lines with less vascular tissue like II-32A should be selected for hightemperature tolerance.

\section{CONCLUSION}

In summary, seed setting in male sterile lines was more sensitive to high temperature than the conventional rice variety and the fertility rate of some male sterile lines decreased significantly when the average daily temperature was above $28^{\circ} \mathrm{C}$, thus the warning high temperature for hybrid rice seed production should be about $2^{\circ} \mathrm{C}$ lower than the recommended temperature for conventional rice varieties. Meanwhile, the male sterile lines 
responded diversely to high temperatures, which was directly connected with the trait of glume closure in response under increased temperature. It may be possible to develop high temperature-tolerant male sterile lines with non-glume closure and less vascular bundles under high temperature.

\section{AUTHOR CONTRIBUTIONS}

XT: responsible for experimental design and organizing; HY: responsible for doing the experiment, data analysis and manuscript preparation; YZ: responsible for assisting in data analysis; BZ: participating in microscopic observation; TM: assisting in experimental design; HX: materials culture; XC: flowering spikelets recording.

\section{FUNDING}

This research was granted by National Natural Science Foundation of China (30971736), Natural Science Foundation

\section{REFERENCES}

Cao, L., Zhao, J., Zhan, X., Li, D., He, L., and Cheng, S. (2003). Mapping QTLs for heat tolerance and correlation between heat tolerance and photosynthetic rate in rice. Chin. J. Rice Sci. 17, 223-227.

Cheng, S. H., Zhuang, J. Y., Fan, Y. Y., Du, J. H., and Cao, L. Y. (2007). Progress in research and development on hybrid rice: a super-domesticate in China. Ann. Bot. 100, 959-966. doi: 10.1093/aob/mcm 121

Das, S., Krishnan, P., Nayak, M., and Ramakrishnan, B. (2014). High temperature stress effects on pollens of rice (Oryza sativa L.) genotypes. Environ. Exp. Bot. 101, 36-46. doi: 10.1016/j.envexpbot.2014.01.004

Hasanuzzaman, M., Nahar, K., Alam, M. M., Roychowdhury, R., and Fujita, M. (2013). Physiological, biochemical, and molecular mechanisms of heat stress tolerance in plants. Int. J. Mol. Sci. 14, 9643-9684. doi: 10.3390/ijms14059643

Jagadish, S. K., Muthurajan, R., Rang, Z. W., Malo, R., Heuer, S., Bennett, J., et al. (2011). Spikelet proteomic response to combined water deficit and heat stress in rice (Oryza sativa cv. N22). Rice 4, 1-11. doi: 10.1007/s12284-011-9059-x

Koike, S., Yamaguchi, T., Ohmori, S., Hayashi, T., Yatou, O., and Yoshida, H. (2015). Cleistogamy decreases the effect of high temperature stress at flowering in rice. Plant Prod. Sci. 18, 111-117. doi: 10.1626/pps.18.111

Li, J., and Yuan, L. (2010). Hybrid rice: genetics, breeding, and seed production. Plant Breed. Rev. 17, 15-158.

Li, J. M., Xin, Y. Y., and Yuan, L. P. (2009). Hybrid Rice Technology Development: Ensuring China's Food Security. IFPRI Discussion Papers. Washington, DC: International Food Policy Research Institute, 271-293.

Li, T. G. (1988). Study on cold resistance of rice at flowering stage. Acta Agron. Sin. $14,66-70$.

Matsui, T., and Kagata, H. (2003). Characteristics of floral organs related to reliable self-pollination in rice (Oryza sativa L.). Ann. Bot. 91, 473-477. doi: 10.1093/ aob/mcg045

Matsui, T., Omasa, K., and Horie, T. (2000). High temperature at flowering inhibits swelling of pollen grains, a driving force for thecae dehiscence in rice (Oryza sativa L.). Plant Produc. Sci. 3, 430-434. doi: 10.1626/pps.3.430

Mesihovic, A., Iannacone, R., Firon, N., and Fragkostefanakis, S. (2016). Heat stress regimes for the investigation of pollen thermotolerance in crop plants. Plant Reprod. 95, 398-411. doi: 10.1007/s00497-016-0281-y

Prasad, P., Boote, K., Allen, L., Sheehy, J., and Thomas, J. (2006). Species, ecotype and cultivar differences in spikelet fertility and harvest index of rice in response to high temperature stress. Field crops Res. 95, 398-411. doi: 10.1016/j.fcr.2005. 04.008

Satake, T., and Yoshida, S. (1978). High temperature-induced sterility in indica rices at flowering. Jpn. J. Crop Sci. 47, 6-17. doi: 10.1626/jcs.47.6 of Hubei Province, China (2013CFA011, 2014CFB225), National Key Technology Research and Development Program of China (2012BDA04B12-3) and Special Fund for Agro-scientific Research in the Public Interest in China (201203029).

\section{ACKNOWLEDGMENTS}

We thank Hubei Allwin High-Tech Seed Co. Ltd. and Dr. Guotao Yang in Southwest University of Science and Technology for their kind offer of seeds for our experiment. We are grateful to professor Chengdao Li of Murdoch University, Australia for his critical review of this manuscript.

\section{SUPPLEMENTARY MATERIAL}

The Supplementary Material for this article can be found online at: http://journal.frontiersin.org/article/10.3389/fpls.2016.01960/ full\#supplementary-material

Seck, P. A., Diagne, A., Mohanty, S., and Wopereis, M. C. S. (2012). Crops that feed the world 7: rice. Food Security 4, 7-24. doi: 10.1007/s12571-012-0168-1

Shen, Y. P., and Wang, G. Y. (2013). Key findings and assessment results of IPCC WGI fifth assessment report. J. Glaciol. Geocryol. 35, 1068-1076.

Singh, S. K., Bhati, P. K., Sharma, A., and Sahu, V. (2015). Super hybrid rice in china and india: current status and future prospects. Int. J. Agric. Biol. 17, 221-232.

Stocker, T., Qin, D., Plattner, G., Tignor, M., Allen, S., Boschung, J., et al. (2013). IPCC, 2013: Summary for Policymakers in Climate Change 2013: the Physical Science Basis, Contribution of Working Group I to the Fifth Assessment Report of the Intergovernmental Panel on Climate Change. Cambridge: Cambridge University Press.

Tian, X., Huang, Y., and Matsui, T. (2008). "Characterizing the rice field climatic factors under high temperature stress at anthesis," in Proceedings of the 5th International Crop Science Congress, Jeju, 19.

Togari, Y., and Kashiwakura, Y. (1958). Studies on the sterility in rice plant induced by superabundant nitrogen supply and insufficient light intensity. Jpn. J. Crop Sci. 27, 3-5. doi: 10.1626/jcs. 27.3

Tu, Q. P., Deng, Z. W., and Zhou, X. L. (1999). Study of regional characteristicson mean annual temperature variation of near 117 years in China. Q. J. Appl. Meteorol. 10, 35-43.

Wang, W. L., Zhu, Q. S., Wang, S. M., and Yang, Q. J. (2011). Study on mechanization hybrid rice seed production technology and combine breeding advances. Agric. Sci. Technol. 12, 90-92.

Wang, Z., Gu, Y. J., and Gao, Y. Z. (1991). Studies on the mechanism of the anthesis of rice III. structure of the lodicule and changes of its contents during flowering. Acta Agron. Sin. 17, 96-101.

Wang, Z., Gu, Y. J., and Gao, Y. Z. (1992). Studies on the mechanism of the anthesis of rice IV. Structure of rice rachilla and it's relations to spikelet-opening and closing. Acta Agron. Sin. 18, 331-336.

Xiao, Y., Pan, Y., Luo, L., Zhang, G., Deng, H., Dai, L., et al. (2011). Quantitative trait loci associated with seed set under high temperature stress at the flowering stage in rice. Euphytica 178, 331-338. doi: 10.1007/s10681-010-0300-2

Yan, H. L., Pan, X. F., Chen, J. Z., Yao, Y. M., Lu, B. L., and Tian, X. H. (2015). Outcrossing seed setting rate was seriously reduced by high-temperature in hybrid rice seed production under field conditions. Chin. J. Rice Sci. 29, 106-110.

Yan, H. L., Xu, Z. R., Chen, J. Z., Yao, Y. M., Shao, P., Wang, Y., et al. (2014). Susceptibility of hybrid rice seed production system to high temperature. Chin. Agric. Sci. Bull. 30, 37-40.

Ye, C., Argayoso, M. A., Redona, E. D., Sierra, S. N., Laza, M. A., Dilla, C. J., et al. (2012). Mapping QTL for heat tolerance at flowering stage in rice using SNP markers. Plant Breed. 131, 33-41. doi: 10.1111/j.1439-0523.2011.01924.x 
Ye, C., Tenorio, F. A., Redona, E. D., Morales-Cortezano, P. S., Cabrega, G. A., Jagadish, K. S. V., et al. (2015). Fine-mapping and validating qHTSF4.1 to increase spikelet fertility under heat stress at flowering in rice. Theor. Appl. Genet. 128, 1507-1517. doi: 10.1007/s00122-015-2526-9

Yoshida, H., Itoh, J., Ohmori, S., Miyoshi, K., Horigome, A., Uchida, E., et al. (2007). Superwoman1-cleistogamy, a hopeful allele for gene containment in GM rice. Plant Biotechnol. J. 5, 835-846. doi: 10.1111/j.1467-7652.2007.00291.x

Zhao, L., Kobayasi, K., Hasegawa, T., Wang, C.-L., Yoshimoto, M., Wan, J., et al. (2010). Traits responsible for variation in pollination and seed set among six rice cultivars grown in a miniature paddy field with free air at a hot, humid spot in China. Agric. Ecosyst. Environ. 139, 110-115. doi: 10.1016/j.agee.2010.07.006
Conflict of Interest Statement: The authors declare that the research was conducted in the absence of any commercial or financial relationships that could be construed as a potential conflict of interest.

Copyright (อ) 2017 Yan, Zhang, Zhang, Chen, Xiong, Matsui and Tian. This is an open-access article distributed under the terms of the Creative Commons Attribution License (CC BY). The use, distribution or reproduction in other forums is permitted, provided the original author(s) or licensor are credited and that the original publication in this journal is cited, in accordance with accepted academic practice. No use, distribution or reproduction is permitted which does not comply with these terms. 